\title{
Clivus erosions following Gradenigo's syndrome- mastoiditis causing VI nerve palsy
}

\author{
Tharsika Karunakaran, Myuran Kaneshamoorthy, Robert Harris
}

St George's Hospital, London, UK

\section{Correspondence to Dr Tharsika Karunakaran; tharsika@doctors.org.uk}

Accepted 26 February 2016

\section{DESCRIPTION}

A 13-year-old boy presented to his general practitioner, with right otalgia, mastoid tenderness and paresis of the right lateral rectus muscle. An MRI showed middle ear cleft opacification only and the patient was treated with oral ciprofloxacin, with resolution of symptoms.

Five months later, he developed a severe occipital headache and had difficulty flexing his neck, accompanied by fever and raised inflammatory markers. There were no signs of acute mastoiditis.

CT showing grossly abnormal appearances of the base of the skull, with areas of widespread erosive change particularly within the clivus (figure 1). There was minimal opacification of the right mastoid (figure 2). Inflammatory change was seen in the longus colli muscle. Trans-sphenoidal clivus biopsies showed granulation tissue only. Tests for tuberculosis and HIV, and a lumbar puncture, were negative. Organisms were seen neither on cytology nor on culture. The symptoms resolved completely after 14 days of intravenous ceftriaxone and metronidazole. The patient was discharged with 2 weeks of oral coamoxiclav. MRI 1 month after treatment showed regression of inflammatory changes, where clivus marrow signal was still affected but the prevertebral soft tissue changes had regressed.

Gradenigo's syndrome $(\mathrm{GS})^{1}$ is mastoiditis that extends to the petrous apex causing dysfunction of the VI cranial nerve. Infective clivus erosions have been reported as a result of allergic fungal rhinosinusitis, ${ }^{2}$ but there are no reported cases of clivus erosions occurring in association with GS. This case is also unique because of the long interval

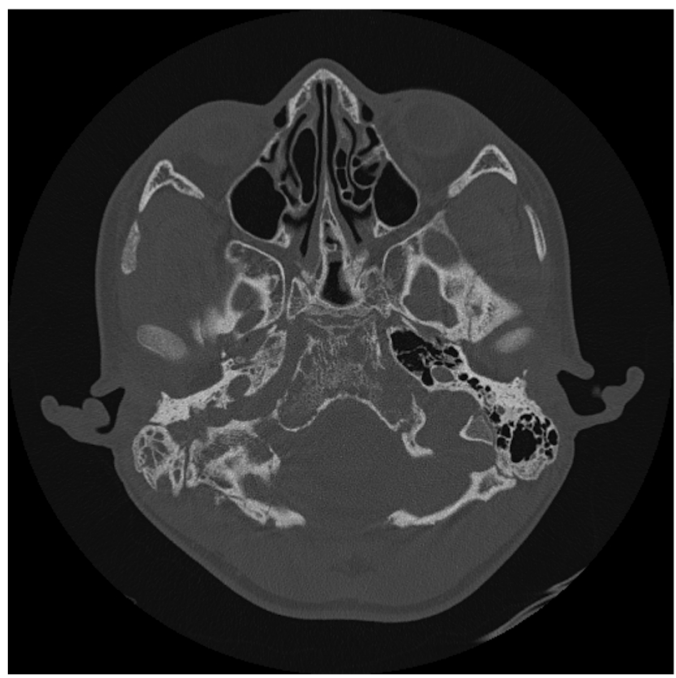

Figure 1 Axial CT showing erosions of clivus and pneumatisation of petrous apex.

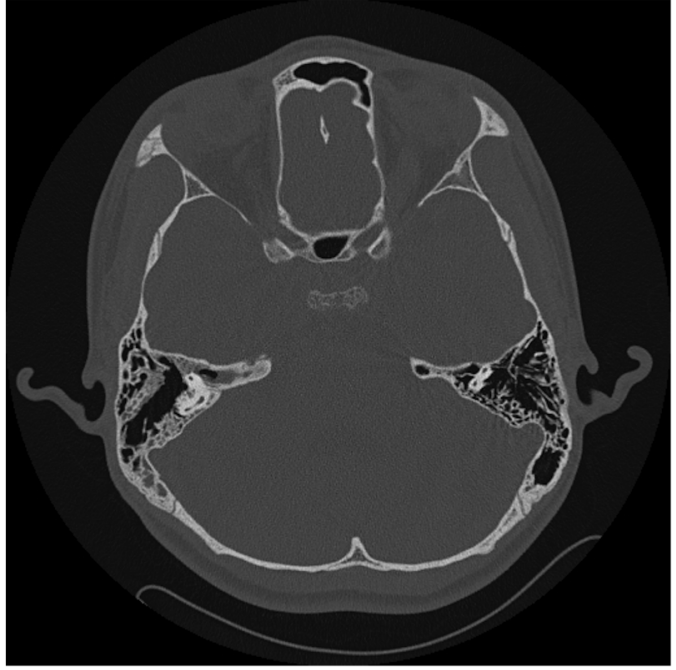

Figure 2 Axial CT showing minimal opacification of the mastoid air cells.

between the initial presentation of GS and the indolent progression leading to extensive radiological changes seen at representation 5 months later.

\section{Learning points}

- Mastoid tenderness associated with a VI nerve palsy could be a presentation of Gradenigo's syndrome-petrous apicitis - as a result of spreading osteomyelitis.

- Taking a thorough medical history of related specialties can be key in uncovering the underlying pathology behind rare presentations.

- A presumed osteomyelitis of the clivus bone secondary to Gradenigo's syndrome responds to antibiotics both clinically and radiologically.

Acknowledgements The authors thank the patient and his parents for consenting to the writing of this report.

Competing interests None declared.

Patient consent Obtained.

Provenance and peer review Not commissioned; externally peer reviewed.

\section{REFERENCES}

1 Gradenigo G. Ueber die paralyse des Nervus abducens bei Otitis. Arch Ohrenheilunde 1907:74:149-87.

2 Meccariello G, Deganello A, Mannelli G, et al. Allergic fungal rhinosinusitis infiltrating anterior skull base and clivus. Auris Nasus Larynx 2013;40:405-8. 
Copyright 2016 BMJ Publishing Group. All rights reserved. For permission to reuse any of this content visit http://group.bmj.com/group/rights-licensing/permissions.

BMJ Case Report Fellows may re-use this article for personal use and teaching without any further permission.

Become a Fellow of BMJ Case Reports today and you can:

- Submit as many cases as you like

- Enjoy fast sympathetic peer review and rapid publication of accepted articles

- Access all the published articles

- Re-use any of the published material for personal use and teaching without further permission

For information on Institutional Fellowships contact consortiasales@bmjgroup.com

Visit casereports.bmj.com for more articles like this and to become a Fellow 